\title{
Pengaruh Uji Antibakteri Ekstrak Rimpang Jahe Terhadap Pertumbuhan Staphylococcus Aureus Dan Escherichia Coli Secara In Vitro
}

\section{Effect Of Antibacterial Test Of Ginger Ginger Extract On The Growth Of Staphylococcus Aureus And Escherichia Coli In Vitro}

\author{
Siti Zamilatul Azkiyah \\ Program Studi Farmasi, Fakultas Ilmu Kesehatan, Universitas Ibrahimy \\ Email: zamilatul@ibrahimy.ac.id
}

\begin{abstract}
ABSTRAK
Permasalahan tentang resistensi semakin meningkat seiring dengan kebutuhan antimikroba sebagai alternatif dalam mengatasi masalah resistensi. Salah satu solusinya yaitu dengan memanfaatkan kandungan dari senyawa metabolit sekunder pada tanaman rimpang-rimpangan seperti rimpang jahe. Kandungan senyawa yang biasanya paling dominan pada jahe seperti minyak atsiri, flavonoid, terpenoid dan fenol. Penelitian ini bertujuan untuk mengetahui pengaruh dari ekstrak rimpang jahe sebagai antbakteri terhadap pertumbuhan Staphylococcus aureus dan Escherichia coli secara in vitro. Penelitian ini termasuk penelitian eksperimental laboratorium dengan rancangan acak lengkap (RAL) yang terdiri dari 7 perlakuan dengan 3 kali ulangan. Hasil penelitian diperoleh bahwa ekstrak etanol rimpang jahe memiliki aktivitas antibakteri terhadap S. Aureus dan E. coli. Pada konsenrasi 20\%, 40\% dan 80\% yang lebih efktif dalam menghambat pertumbuhan kedua bakteri tersebut. Semakin tinggi tingkatan konsentrasi ekstrak maka diameter zona hambat dari pertumbuhan bakteri juga semakin besar. Terhambatnya pertumbuhan bakteri ini diduga adanya pengaruh dari kandungan pada rimpang jahe.
\end{abstract}

Kata Kunci: Rimpang Jahe, Staphylococcus aureus, Escherichia coli, antibakteri

\section{ABSTRACT}

The problem of resistance is increasing along with the need for antimicrobials as an alternative in overcoming resistance problems. One solution is to utilize the content of secondary metabolite compounds in rhizome plants such as ginger. The content of compounds that are usually the most dominant in ginger such as essential oils, flavonoids, terpenoids and phenols. This study aims to determine the effect of ginger rhizome extract as an antibacterial on the growth of Staphylococcus aureus and Escherichia coli in vitro. This study was a laboratory experimental study with a completely randomized design (CRD) consisting of 7 treatments with 3 replications. The results showed that the ethanol extract of ginger rhizome had antibacterial activity against $S$. aureus and E. coli. At concentrations of $20 \%, 40 \%$ and $80 \%$ which are more effective in inhibiting the growth of these two bacteria. The higher the extract concentration level, the larger the diameter of the inhibition zone from bacterial growth. This inhibition of bacterial growth is thought to have an effect on the content of the ginger root.

Keywords: Ginger rhizome, Staphylococcus aureus, Escherichia coli, antibacterial

\section{PENDAHULUAN}

Penyakit infeksi yang terjadi di Indonesia sudah terjadi sejak dulu dan biasanya penanggunalangannya dengan memberikan obat pada penderita infeksi, seperti obat antimikroba (Dzulkarnain, 2004). Antimikroba merupakan antobiotik antifungsional yang bisa menyebabkan beberapa mikroba khususnya mikroba patogen 
menjadi resisten, artinya beberapa mikroba dapat beradaptasi terhadap obat tersebut dan tidak mampu lagi diatasi dengan obat tersebut. Seiring dengan adanya peningkatan resistensi terhadap obat antimikroba menyebabkan beberapa peneliti dan industri menciptakan obat antimikroba yang baru dalam mengatasi tingginya tingkat resistensi pada suatu penyakit. Oleh karena itu, hingga saat ini banyak dikembangkan berbagai macam antibakteri yang lebih efisien dan tingkat resistensinya rendah, salah satunya dengan memanfaatkan kandungan pada tanaman sebagai antimikroba (Yustina 2001).

Pada umumya bakteri patogen yang menyerang pada manusia maupun hewan mamalia lainnya adalah bakteri S. aureus dan E. coli. Bakteri S. aureus termasuk dalam jenis bakteri gram positif dan dalam jumlah $105 \mathrm{CFU} / \mathrm{ml}$ dapat menyebabakan toksik. Sedangkan bakteri E. coli termasuk kedalam golongan bakteri gram negatif, dengan bentuk batang, bersifat aerob atau anaerob fakultatif (Pleczar dan Chan., 1988). Dalam jumlah $106 \mathrm{CFU} / \mathrm{ml}$ bakteri E. coli dapat menyebabkan toksik (SNI, 2009). Selama ini penganggulangan dari bakteri patogen ini dilakukan menggunakan antimikroba yang dapat menyebabkan resistensi. Sehingga beberapa penelitian sudah mulai mencari solusi dengan memanfaatkan kandungan pada tanaman yang berpotensi sebagai antimikroba. Pemanfaatan antimikroba pada tanaman memiliki kandungan kimia yang secara alami tidak menimbulkan efek samping berbahaya dan ramah lingkungan, tidak membutuhkan biaya yang besar dan tanmaannya mudah tumbuh dan di dapatkan di lingkungan sekitar (Tim Bina Karya Tani, 2008).

Salah satu tanaman yang berpotensi dan mudah didapatkan dan ditanam adalah jahe. Jahe merupakan jenis kelompok rimpang-rimpangan (Famili Zingiberaceae) dengan nama latin Zingiber officinale. Selama ini tanaman jahe yang dimanfaatkan adalah bagian rimpangnya dan sebagai bahan baku pembuatan obat-obatan maupun sebagai bahan tambahan pangan pada masakan (Tim Bina Karya Tani, 2008).

Kandungan senyawa pada tanaman jahe yang dimanfaatkan merupakan hasil dari proses metabolit sekunder seperti golongan flavonoid, terpenoid dan minyak atsiri serta fenol. Kandungan senyawa tersebut berpotensi 
menghambat pertumbuhan dari beberapa bakteri patogen yang dapat menyebabkan penyakit pada Manusia, bakteri patogen yang paling banyak merugikan anatara lain bakteri E. coli, B. subtilis, S. aureus (Nursal et al., 2006). Berdasarkan latar belakang yang telah dijelaskan maka dilakukan uji antibakteri ekstrak rimpang jahe terhadap pertumbuhan Staphylococcus aureus dan Escherichia coli secara in vitro.

\section{METODE PENELITIAN}

Pada penelitian ini termasuk dalam penelitian eksperimental skala laboratorium dengan rancangan acak lengkap (RAL) yang terdiri dari 7 perlakuan dan masing-masing perlakuan dilakukan 3 kali ulangan. Tempat penelitian di Laboratorium Mikrobiologi Prodi Farmasi Fakultas Ilmu Kesehatan Universitas Ibrahimy pada bulan Maret-Agustus 2019.

Alat yang digunakan antara lain rotary evaporator, laminar air flow (LAF), beaker gelas, tabung reaksi, cawan petri, gelas ukur, Erlenmeyer, kaca arloji, ayakan, rak tabung reaksi, timbangan analitik, labu ekstraksi, incubator, pengaduk, termometer, autoklaf, mikropipet, jarum ose, pinset, alumunium foil, alat tulis dan kamera. Bahan yang digunakan anatra lain isolate bakteri $S$. aureus dan E.coli, rimpang jahe, CMC, akuades, etanol, media NA, asam sulfat, Natrium klorida $0.9 \%$ dan tablet Ciprofloxacin.

Tahapan penelitian ini meliputi:

\section{Persiapan Sampel}

Tahap awal persiapan sampel yaitu rimpang jahe yang telah dipanen dicuci bersih menggunakan air mengalir supaya kotoran yang masih menempel hilang, selanjutnya proses perajangan dengan ukuran yang kecil-kecil supaya mudah dikeringkan. Berikutnya rimpang jahe sudah dikeringkan dibawah naungan hingga kering artinya kandungan airnya sangat rendah dihaluskan menggunakan blender dan diayak mengguanakan ayakan ukuran 65 mesh. Penyimpanan serbuk rimpang jahe menggunakan wadah tertutup yang terbuat dari kaca supaya kualitas simplisia tetap bagus (Gunawan dan Mulyani, 2004).

\section{Pembuatan Ekstrak}

Proses ekstraksi rimang jahe dilakukan menggunakan metode maserasi yaitu dengan cara sebanyak 60 gram serbuk rimpang jahe dalam erlemeyer dan ditambahkan $225 \mathrm{~mL}$ etanol $96 \%$ bagian ujung ditutup rapat 
menggunakan alumunium foil, selanjutnya sampel didiamkan selama lima hari dengan dilakukan pengadukan secara berkala. Sampel yang telah direndam selama 5 hari disaring menggunakan kertas saring dan bagian atas atau filtrate yang diambil, sedangkan ampasnya ditambahkan etanol kembali sebanyak $75 \mathrm{~mL}$ dan direndam kembali selama kurang lebih dua hari dengan pengadukan secara berkala, kemudian setelah dua hari dilakukan penyaringan seperti sebelumnya.

Filtrat hasil penyaringan dikumpulkan menjadi satu wadah dan dilakukan proses pemisahan pelarut dari sampel menggunakan rotary evaporator untuk mendapat ekstrak kental dari rimpang jahe, biasanya masih berupa crude ekstrak. Sebelum disimpan crude ekstrak memiliki tekstur kental dan dibiarkan terlebih dahulu terbuka disuhu ruangan supaya sisa pelarut menguap. Proses selanjutnya yaitu penyimpanan dalam wadah gelas dengan kondisi tertutup dan digunakan untuk tahapan uji selanjutnya (Depkes RI, 1986).

\section{Sterilisasi Alat}

Sterilisasi alat yang digunakan untuk penelitian bertujuan supaya

mensterilkan bahan dan alat yang akan digunakan dan tidak menjadi kontaminan. Proses sterilisasi biasanya menggunakan oven pada alat gelas dengan suhu $170{ }^{0} \mathrm{C}$ selama \pm 2 jam. Sedangkan sterilisasi alat besi seperti jarum ose dan pinset menggunakan teknik pembakaran menggunakan lampu bunsen. Sterilisasi media dilakukan dengan autoklaf pada suhu $121{ }^{0} \mathrm{C}$ selama \pm 15 menit (Lay dan Hastowo, 1992).

\section{Pembuatan Larutan Kontrol Negatif dan Positif}

Pembuatan kontrol negative menggunakan $\mathrm{CMC} \quad 1 \%$ dengan mencampurkan sebanyak 1 gram CMC dalam $100 \mathrm{~mL}$ akuades steril dan dihomogenkan.

Pembuatan kontrol positif menggunakan serbuk dari tablet Ciprofloxacin masing-masing sebanyak $500 \mathrm{mg}$ dalam CMC sehingga diperoleh larutan Ciprofloxacin $50 \mu \mathrm{g} / 50 \mu \mathrm{l}$.

\section{Pembuatan Larutan Uji}

Konsentrasi larutan yang diujikan yaitu 5\%; 10\%; 20\%; 40\%; dan $80 \% \mathrm{~b} / \mathrm{v}$ dengan cara menimbang crude ekstrak etanol dari rimpang jahe sebanyak 0,05 g; 0,1 g; 0,2 g; 0,4 g; dan $0,8 \mathrm{~g}$, selanjutnya sampel dilarutkan dalam larutan CMC $1 \mathrm{~mL}$. 


\section{Pembuatan Media}

Media yang digunakan adalah media NA (Nutrient Agar) dengan mencampurkan 0.46 gr dan $20 \mathrm{~mL}$ akuades (23gram $/ 1000 \mathrm{~mL})$ dalam Erlenmeyer. Selanjutnya distirer dengan penangan hingga air mendidih supaya homogen. Hasilnya sebanyak $5 \mathrm{~mL}$ dimasukkan dalam tabung reaksi dan ditutup dengan alumunium foil. Selanjutnya semua media disterilisasi menggunakan autoklaf selama 15 menit dengan suhu $121{ }^{0} \mathrm{C}$. Media yang telah disterilisasi diletakkan dalam suhu ruang dengan posisi tabung dimiringkan kurang lebih $30^{\circ}$ kemiringannya. Media yang telah padat bisa digunakan untuk tahap selanjutnya yaitu inokulasi bakteri (Lay, 1994).

\section{Pembuatan Suspensi Bakteri Uji}

Proses suspense bakteri uji dilakukan dengan cara menginkolulasi bakteri kedalam tabung yang berisi 2 $\mathrm{mL}$ larutan Natrium klorida $0.9 \%$ menggunakan jarum ose. Sebagai perbandingan menggunakan standar kekeruhan larutan Mc. Farland sebagai perbandingan untuk untuk setiap sampel uji bakteri (Vandepitte et al, 2005).

\section{Pembuatan Media Pengujian}

Media NA sebanyak $10 \mathrm{~mL}$ dituangkan dalam 9 cawan petri dan ditunggu hingga memadat. Pada bagian dasar diletakkan pencadang baja secara tersebar dan tidak tumpang tindih. Proses selanjutnya dengan menuangkan suspensi bakteri sebanyak $25 \mathrm{ml}$ ke masing-masing cawan petri jadi posisi pencadang baja ada ditengah dan diambil secara aseptik dari media hingga membetuk sumur atau cekungan yang berfungsi sebagai uji antibakteri.

\section{Uji Aktivitas Antibakteri secara In-} vitro

Hasil ekstrasi rimpang jahe yang berupa crude ekstrak dibuat menjadi larutan dengan konsentrasi 5\%, 10\%, $20 \%, 40 \%$ dan $80 \%$, larutan CMC $1 \%$ (kontrol negatif), larutan Ciprofloxacin $50 \mu \mathrm{g} / 50 \quad \mu \mathrm{l} \quad$ (kontrol positif). Selanjutnya menggunakan mikropipet diambil $50 \mu \mathrm{l}$ dan diinokulasikan pada sumur atau cekungan secara aseptik dalam semua media. Tahap selanjutnya cawan petri disimpan dalam incubator dengan suhu $37{ }^{\circ} \mathrm{C}$ selama 24 jam untuk proses inkubasi atau pertumbuhan bakteri.

\section{Pengamatan dan Pengukuran}

Cawan petri yang telah diinkubasi diamati diameter zona bening/hambat yang ada disekitar sumur atau cekungan. Zona bening merupakan respon kepekaan dari bakteri 
uji terhadap senyawa yang bersifat antibakteri. Cara menghitung zona bening dengan mengukur diameter zona bening dikurangi diameter cekungan yaitu $7 \mathrm{~mm}$. Penggolongan Davis and Stout (2017) merupakan acuan penggolongan diameter zona bening terhadap daya antibakterinya

Analisa data hasil uji anti bakteri menggunakan metode analisa varian satu arah pada program SPSS dengan tingkat kepercayaan $\alpha=0.05$ dan uji lanjutan yaitu uji Duncan.

\section{HASIL DAN PEMBAHASAN}

Filtrat hasil ekstrasi etanol rimpang jahe diperoleh sebanyak 225 $\mathrm{mL}$, berwarna kuning kehitaman dan dapat menghasilkan ekstrak kental sebanyak 5.37 gr dan berwarna kuning gelap. Metode yang digunakan adalah metode difusi agar yang telah dimodifikasi (Difusi Kirby dan Bauer) dengan cara mengukur diameter cekungan dan zona bening yang terbentuk dari aktivitas bakteri $\mathrm{S}$. aureus dan E. coli (Gambar 1).

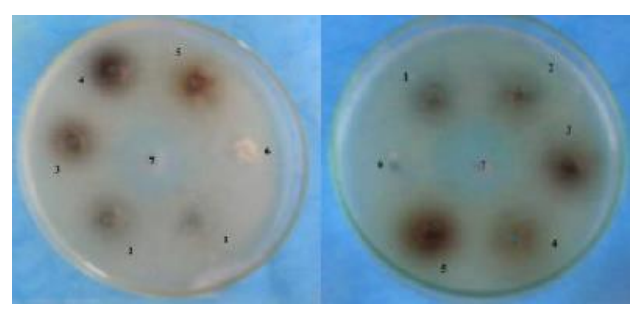

Gambar 1. Zona bening dari (a) S. aureus dan (b) E. coli
Tabel 1 Hasil Pengukuran Rata- rata Diameter Zona Hambat Ekstrak Etanol Rimpang Jahe terhadap Pertumbuhan Bakteri Staphylococcus aureus, Escherichia coli

\begin{tabular}{|c|c|c|}
\hline \multirow[t]{2}{*}{ Konsentrasi } & \multicolumn{2}{|c|}{$\begin{array}{c}\text { Rata- rata Diameter Zona } \\
\text { Hambat Pertumbuhan } \\
\text { Bakteri }(\mathrm{mm})\end{array}$} \\
\hline & $\begin{array}{c}\text { Staphylococcus } \\
\text { aureus }\end{array}$ & $\begin{array}{c}\text { Escherichia } \\
\text { coli }\end{array}$ \\
\hline $5 \%$ & 8.17 & 9.17 \\
\hline $10 \%$ & 9.83 & 10.33 \\
\hline $20 \%$ & 10.67 & 11.17 \\
\hline $40 \%$ & 11.17 & 12.50 \\
\hline $80 \%$ & 12.33 & 14.17 \\
\hline Kontrol (+) & 26.33 & 29.17 \\
\hline Kontrol (-) & 0.00 & 0.00 \\
\hline
\end{tabular}

Berdasarkan analisis data menunjukkan diameter zona hambat aktivitas bakteri uji memiliki nilai signifikansi $0.000 \quad(\mathrm{p}<0.05)$, hal ini menunjukkan bahwa terdapat pengaruh pada setiap perlakuan dan pada semua perlakuan menunjukkan adanya aktivitas dari bakteri uji. Hasil uji lanjutan menggunakan Duncan untuk mengetahui perlakuan mana yang paling memiliki efek yang besar (Simanjuntak, 2008). Hasilnya menunjukkan kontrol positif berbeda secara nyata dibandingkan perlakuan lainnya. Sedangkan zona hambat yang dibentuk pada perlakuan kontrol positif memiliki zona hambat yang lebih besar dari pada bakteri E.coli yaitu $29.2 \mathrm{~mm}$ dan $\mathrm{S}$. aureus sebesar $26.3 \mathrm{~mm}$. Pada bakteri S. aureus diameter zona hambat pada konsentrasi 5\% (8.17 mm), 10\% (9.83 $\mathrm{mm})$ dan $80 \% \quad(12.33 \quad \mathrm{~mm})$ 
menunjukkan perbedaan secara nyata terhadapperlakuan lainnya, sedangkan pada konsentrasi $20 \%$ (10.67 $\mathrm{mm})$ dan $40 \%(11.17 \mathrm{~mm})$ tidak berbeda secara nyata.

Uji Duncan pada uji bakteri E. coli menunjukkan konsentrasi 5\% (9.17 $\mathrm{mm}), 40 \%$ (12.5 mm), 80\% (14.17 mm) menunjukkan perbedaan secara nyata, artinya terdapat pengaruf antara ekstrak rimpang jahe terhadap pertumbuhan bakteri. Sedangkan konsentrasi $10 \%$ $(10.33 \mathrm{~mm})$ dan $20 \%$ (11.67 mm) tidak menunjukkan perbedaan secara nyata, artinya ekstrak memiliki daya hambat yang rendah terhadap pertumbuhan bakteri E. coli. Jadi konsentrasi ekstrak yang paling tinggi dalam mengahambat pertumbuhan kedua bakteri uji adalah pada konsentrasi $80 \%$. Dan konsentrasi terendah dalam menghambat pertumbuhan kedua bakteri adalah konsentrasi 5\%. Hal ini menunjukkan semakin tinggi konsentrasi maka daya hambat yang dibentuk semakin besar dengan menunjukkan luasan diameter zona bening/hambat yang juga besar.

Aktivitas zona hambat yang dibentuk dari respon kepekaan bakteri terhadap kandungan senyawa dari ekstrak rimpang jahe pada kedua bakteri uji berbeda. Hal ini dibebabkan struktur penyusun dinding sel yang berbeda, pada bakteri E.coli termasuk dalam jenis bakteri gram negative dengan struktur dinding sel yang tersusun atas satu lapisan peptidoglikan yang tipis yang dilapisi lagi oleh membrane bagian luarnya sehingga lebih mudah hancur dengan adanya senyawa antibakteri. Pada bakteri S. aureus memiliki struktur dinding sel yang lebih tebal karena lapisan peptidoglikannya tebal dan kaku serta mengandung asam teikoat dan termasuk kedalam golongan bakteri gram positif (Radji, 2011). Mekanisme kerja senyawa antibakteri yang dapat hambat pertumbuhan bakteri dengan cara menghamba topoisomerase II (DNA girase) dan topoisomerase VI pada bakteri.

Tingkat kepekaan kedua bakteri uji juga berbeda yaitu bakteri gram positif memiliki tingkat kepekaan yang lebih tinggi dibandingkan bakteri gram negative terhadap lingkungan fisik dan kimia (Radji, 2011). Sehingga pada bakteri gram negative memiliki respon yang lebih tahan terhadap antibiotic atau lingkungan fisik/kimia. Hal ini disebabkan karena bakteri memproduksi eksopolisakarida berupa alginate yang tekstur berupa gel dan membentuk biofilm (Mayasari, 2006). Biofilm 
biasanya cenderung membentuk koloni dan dapat tahan terhadap antibiotic dan bahan antibakteri lainnya (Todar, 2009).

$$
\text { Bakteri memproduksi }
$$

eksopolisakarida (EPS) berupa alginat yang berbentuk gel kental di sekeliling bakteri. Alginat memungkinkan bakteri untuk membentuk biofilm, yaitu kumpulan koloni sel-sel bakteri yang menempel pada suatu permukaan (Mayasari, 2006). Menurut Todar (2009), kecenderungan berkolonisasi dalam bentuk biofilm membuat bakteri gram negative tahan terhadap antibiotik atau bahan antibakteri lain.

Rimpang jahe secara umum mengandung antimikroba yaitu golongan senyawa bioaktif yang diduga memiliki aktitas antibakteri seperti minyak atsiri, flavonoid, fenol dan terpenoid (Nursal et al, 2006). Sedangkan kandungan dominan dan menjadi ciri khas dari rimpang jahe adalah senyawa fenolik seperti shageol, gingerol, seskuiterpen, zingiberol dan masih banyak kandungan lainnya namun konsentrasinya sangat sedikit sekali (Aprilia, 2010).

\section{SIMPULAN DAN SARAN}

Kesimpulan peneltian ini adalah tingkat konsentrasi berbanding lurus dengan diameter zona hambat bakteri uji yang menunjukkan adanya pengaruh aktivitas dari kandungan senyawa dari Ekstrak rimpang jahe terhadap pertumbuhan bakteri. Konsentrasi yang paling efektif pada kedua bakteri uji adalah konsentrasi $80 \%$.

Saran pada penelitian selanjutnya perlu dilakukan penelitian lebih lanjut untuk mengetahui senyawa spesifik yang berkhasiat sebagai antibakteri pada rimpang jahe ( $Z$. officinale) dan aktivitas antibakteri terhadap bakteri patogen lain.

\section{DAFTAR PUSTAKA}

Ajizah, A. 2004. Sensitivitas Salmonella typhimurium Terhadap Ekstrak Daun Psidium guajava $L$. Bioscientiae. 1(1): 31-38.

Dalimartha, S. 2007. Atlas Tumbuhan Obat Indonesia. Jilid 2. Trubus Agriwidya, Jakarta.

Davis, W.W and Stout, T.R. 1971. Disc Plate Methods of Microbiological Antibiotic Assay. Microbiology. 22(4): 659-665.

Departemen Kesehatan RI. 1986. Sediaan Galenik. Departemen Kesehatan RI, Jakarta. 
Djide dan Sartini. 2008. Dasar-Dasar Mikrobiologi Farmasi. Lephas, Makasar.

Gunawan, D dan Mulyani, S. 2004. Farmakognosi. Swadaya. Jakarta.

Jawetz, et al. 2007. Mikrobiologi Kedokteran. Edisi 23. Salemba Medika, Jakarta.

Lay, B.W. 1994. Analisis Mikroba di Laboratorium. Edisi 1. Raja Grafindo Persada, Jakarta.

Lay, B.W dan Hastowo, S. 1992. Mikrobiologi. IPB, Bogor.

Mayasari, E. 2006. Pseudomonas aeuginosa: Karakteristik, Infeksi dan Penanganan. USU Repository.

Nurwidodo. 2006. Pencegahan dan Promosi Kesehatan Secara Tradisonal. Jurnal Humanity. 1(2): 96-105.

Radji, M. 2011. Mikrobiologi. Buku Kedokteran ECG, Jakarta.

Simanjuntak, M.R. Ekstraksi dan Fraksinasi Komponen Ekstrak Daun Tumbuhan Senduduk (Melastoma malabathricum L) serta Pengujian Efek Sediaan Krim Terhadap Penyembuhan Luka Bakar. [skripsi]. Fakultas Farmasi USU, Medan.

Siregar, S.F. 2009. Uji Aktivitas Antibakteri Ekstrak Etanol dan Air Rebusan Kulit Batang Ingul (Toona sinensis M. Roem) Terhadap Beberapa Bakteri. [skripsi]. Fakultas Farmasi USU, Medan.
Syamsuhidayat SS dan Hutapea JR. 1991. Inventaris Tanaman Obat Indonesia.

Departemen Kesehatan RI, Jakarta. Todar, K. 2009. Pseudomonas aeruginosa. University of Wisconsin Madison Department of Bacteriology.

Vandepitte, et al. 2005. Prosedur Laboratorium Dasar untuk Bakteriologis Klinis. Edisi 2. Buku Kedokteran EGC, Jakarta.

Victor, L. 1980. Antibiotics in Laboratory Test. The Williams and Wilkins Company, USA.

Zulkifli. 2004. Pengobatan Tradisional Sebagai Pengobatan Alternatif harus Dilestarikan. Karya Ilmiah. FKM USU,Medan

Aprilia, F. 2010. Efektifitas Ekstrak Jahe (Zingiber officinale Rosc.) 3,13\% dibandingkan Ketokonazol $2 \% \quad$ Terhadap Pertumbuhan Malassezia sp. pada Ketombe. Artikel Ilmiah. Fakultas Kedokteran. Universitas Diponegoro. Semarang.

Bonang, G. dan E. S Koeswardono. 1979. Mikrobiologi Kedokteran Untuk Laboratorium Dan Klinik. Gramedia. Jakarta.

Dzen, S. M., Roektiningsih., S. Sanarto dan W. Sri. 2003. Bakteriologi Medik. Bayumedia Publishing. Jakarta.

Fitri, L. 2010. The effect of Michelia alba Bark Extract to The Growth of Salmonella typhii and Candida albicans. Jurnal Natural 10 (1): 27-30. 
Khairani, M. 2009. Pengaruh Sediaan Teh (Camellia sinensis (L) $O$. Kuntze) dan Madu Terhadap Bakteri Salmonella typhi Schroeter dan Staphylococcus aureus Rosenbach. [Skripsi]. Universitas Andalas. Padang.

Mulyani, S. 2010. Fakultas Farmasi UGM. Komponen dan Antibakteri dari Fraksi Kristal Minyak Zingiber Zerumbet. Majalah Farm asi Indonesia, 21(3), 178-184.

Nursal, W., Sri dan Wilda S. 2006. Bioaktifitas Ekstrak Jahe (Zingiber officinale Roxb.) Dalam Menghambat
Pertumbuhan Koloni Bakteri Escherichia coli dan Bacillus subtilis. Jurnal Biogenesis 2(2): 64-66.

Tim Bina Karya Tani, 2009. Budidaya Tanaman Jahe. Yrama Widya. Bandung.

Volk, W. A dan M. F Wheler. 1991. Mikrobiologi Dasar Jilid 2. Erlangga. Jakarta.

Wulandari, Y. M. 2011. Karakteristik Minyak Atsiri Beberapa Varietas Jahe (Zingiber Officinale) Teknologi Pertanian. Jurnal Kimia dan Teknologi. 